medRxiv preprint doi: https://doi.org/10.1101/2022.01.16.22269370; this version posted January 16, 2022. The copyright holder for this preprint (which was not certified by peer review) is the author/funder, who has granted medRxiv a license to display the preprint in All rights reserved. No reuse allowed without permission.

\title{
JOINT CONTRIBUTION OF MARKERS OF NEURODEGENERATION AND HYPERCHOLESTEROLEMIA TO DEMENTIA RISK
}

Laura Perna ${ }^{\mathrm{a}, \mathrm{b} *}$, Ute Mons ${ }^{\mathrm{c}, \mathrm{d} *}$, Hannah Stocker ${ }^{c, e}$, Léon Beyer, ${ }^{\mathrm{f}, \mathrm{g}}$ Konrad Beyreuther ${ }^{\mathrm{e}}$, Kira Trares ${ }^{\mathrm{c}, \mathrm{e}, \mathrm{h}}$, Bernd Holleczek $k^{\mathrm{i}}$ Ben Schöttker ${ }^{\mathrm{c}, \mathrm{e}}$, Robert Perneczky ${ }^{\mathrm{b}, \mathrm{j}, \mathrm{k}, \mathrm{l}, \mathrm{m}}$, Klaus Gerwert $^{\mathrm{f}, \mathrm{g}}$, Hermann Brenner ${ }^{\mathrm{c}, \mathrm{e}}$
a) Department of Translational Research in Psychiatry, Max Planck Institute of Psychiatry, Munich, Germany.
b) Division of Mental Health of Older Adults, Department of Psychiatry and Psychotherapy, University Hospital, LMU, Munich, Germany.
c) Division of Clinical Epidemiology and Aging Research, German Cancer Research Center (DKFZ), Heidelberg, Germany.
d) Department of Cardiology, Faculty of Medicine and University Hospital Cologne, University of Cologne, Cologne, Germany.
e) Network Aging Research (NAR), Heidelberg University, Heidelberg, Germany.
f) Faculty of Biology and Biotechnology, Department of Biophysics, Ruhr-University Bochum, Bochum, Germany
g) Center for Protein Diagnostics (ProDi), Ruhr-University Bochum, Bochum, Germany
h) Medical Faculty, Heidelberg University, 69120 Heidelberg, Germany
i) Saarland Cancer Registry, 66117 Saarbrücken, Germany.
j) Ageing Epidemiology (AGE) Research Unit, School of Public Health, Imperial College London, UK.
k) German Center for Neurodegenerative Diseases (DZNE), Munich, Germany.
I) Munich Cluster for Systems Neurology (SyNergy), Munich, Germany.
m) Sheffield Institute for Translational Neurology (SITraN), University of Sheffield, Sheffield, UK

*Both authors contributed equally.

Corresponding author: Laura Perna, Department of Translational Research in Psychiatry, Max Planck Institute of Psychiatry, 80804 Munich, Germany. Phone: +4989-30622 576. Fax: -42-89-30622 444. Email: laura_perna@psych.mpg.de NOTE: This preprint reports new research that has not been certified by peer review and should not be used to guide clinical practice. 
medRxiv preprint doi: https://doi.org/10.1101/2022.01.16.22269370; this version posted January 16, 2022. The copyright holder for this preprint (which was not certified by peer review) is the author/funder, who has granted medRxiv a license to display the preprint in All rights reserved. No reuse allowed without permission.

\begin{abstract}
Background The examination of markers of neurodegeneration (glial fibrillary acidic protein; GFAP, neurofilament light chain; NfL, phosphorylated tau181; p-tau181) among individuals with high comorbidity of neurodegenerative and cerebrovascular disease and their interplay with vascular risk factors, particularly high cholesterol levels, might contribute to explaining the link between body and brain. The aim of this study was to assess whether the association of GFAP, NfL, and p-tau181 with dementia risk varies depending on levels of total cholesterol (TC) and $A P O E \varepsilon 4$ genotype.
\end{abstract}

Methods Nested case-control study embedded within a population-based cohort and including 768 older adults (261 dementia cases and 508 randomly selected controls) followed for up to 17 years with regard to clinical diagnosis of various age-related diseases. GFAP, NfL, and p-tau181 were measured in baseline blood samples using the Single-Molecule Array (Simoa) Technology (Quanterix, USA) and categorized into high (quartile 4) versus low (quartiles 1-3). Logistic regression analyses and spline regression models for dose-response analyses were used. ROC curves by cholesterol levels were also calculated.

Results The risk of a dementia diagnosis was significantly increased between participants with high vs. low levels of GFAP and NfL and the risk substantially varied by TC levels. For GFAP and NfL the ORs of a dementia diagnosis were 5.10 (2.4510.60) and 2.96 (1.43-6.14) in participants with high and 2.44 (1.47-4.07) and 1.15 (0.69-1.92) in those with low TC. APOE $\varepsilon 4$ genotype further modified the strength of the associations with different patterns, depending on specific marker and type of dementia. No significant association was seen with p-tau181.

Conclusions These results suggest that in the general population blood GFAP and $\mathrm{NfL}$ are better predictors of dementia than p-tau181 and that their associations with 
medRxiv preprint doi: https://doi.org/10.1101/2022.01.16.22269370; this version posted January 16, 2022. The copyright holder for this preprint (which was not certified by peer review) is the author/funder, who has granted medRxiv a license to display the preprint in All rights reserved. No reuse allowed without permission.

dementia risk are highly amplified by hypercholesterolemia, also depending on $A P O E$ $\varepsilon 4$ genotype.

\section{Introduction}

Dementia is a progressive disorder characterized by deterioration of cognitive, functional, and behavioral abilities. It has long been established that physical and mental health are fundamentally linked and that a healthy body is an essential precondition of a healthy brain and vice versa. One of the main mechanisms linking body and brain health is the maintenance of a good vascular health ${ }^{1-5}$ and there is strong evidence indicating that several modifiable risk factors for dementia are also risk factors for vascular pathology ${ }^{6}$ and that better cardiovascular health leads to better cognitive health..$^{2,7-10}$

In previous work, we found that the presence of hypercholesterolemia and cardiovascular pathologies modified the association of the apolipoprotein $\mathrm{E}(A P O E)$ $\varepsilon 4$ genotype with cognitive function ${ }^{11}$. Here we ask whether blood markers of neurodegeneration contribute to explaining the link between hypercholesterolemia and cognitive decline, also depending on $A P O E \varepsilon 4$ genotype and the presence of vascular pathologies. As blood markers, we selected glial fibrillary acidic protein (GFAP), neurofilament light chain (NfL), and phosphorylated tau181 (p-tau181), because all these markers have been consistently associated with dementia or dementia risk, and GFAP and NfL also with cerebrovascular disease. ${ }^{12-20}$ Altered levels of GFAP, an astrocytic cytoskeletal protein serving as a marker of abnormal activation and proliferation of astrocytes due to neuronal damage, could also point to a possible dysregulation of brain cholesterol synthesized by astrocytes, whose interconnections with peripheral cholesterol are yet unexplored. ${ }^{21-22}$ Furthermore, astrocytes abundantly express ApoE protein, the principal lipid carrier in brain, 
medRxiv preprint doi: https://doi.org/10.1101/2022.01.16.22269370; this version posted January 16, 2022. The copyright holder for this preprint (which was not certified by peer review) is the author/funder, who has granted medRxiv a license to display the preprint in All rights reserved. No reuse allowed without permission.

including cholesterol, and the $\varepsilon 4$ allele of the $A P O E$ gene increases low-density lipoprotein cholesterol, ${ }^{23}$ which is particularly deleterious to vascular health. APOE $\varepsilon 4$ is also a risk factor for Alzheimer's disease $(A D)$ and, to a lesser extent, for vascular dementia. ${ }^{24-25}$

Most dementia biomarker studies have been conducted in clinic-based cohorts including very narrow populations ${ }^{26-27}$ and mostly focusing on AD-pathology. We believe that in order to understand the impact of markers of neurodegeneration on dementia fully, we need to focus on representative populations with mixed pathologies (comorbidity of neurodegenerative and cerebrovascular disease) and analyze how such markers unfold in synergism with other risk factors. Here, we aimed to focus on total cholesterol (TC) and investigated the association between GFAP, NfL, and p-tau181 with dementia risk by exploring whether the strength of the association varied depending on levels of TC, APOE \&4 genotype, and the presence of vascular pathology prior to or at the time of the measurement of markers of neurodegeneration.

\section{Methods}

\section{Study population}

Data are based on a nested case-control study within a community-based prospective cohort of older adults followed for up to 17 years with regard to clinical diagnosis of various age-related diseases and mortality (the ESTHER study). ESTHER participants $(n=9,940)$ were recruited in 2000-2002 in Saarland, a southwestern German state. Eligibility criteria were age between $50-75$ years, sufficient knowledge of the German language, residence in Saarland, and willingness to attend a general health examination performed by general practitioners (GPs). ${ }^{28}$ No specific exclusion criteria were applied, as this would have impaired the generalizability of the ESTHER study. ${ }^{29}$ Both at baseline and at follow-up 
medRxiv preprint doi: https://doi.org/10.1101/2022.01.16.22269370; this version posted January 16, 2022. The copyright holder for this preprint (which was not certified by peer review) is the author/funder, who has granted medRxiv a license to display the preprint in All rights reserved. No reuse allowed without permission.

measurements, participants provided health information and biological samples, including blood samples, which were stored at $-80^{\circ} \mathrm{C}$. GPs provided available medical records. The ESTHER study was approved by the Ethics Committee of the Medical Faculty at Heidelberg University and the Physicians' Board of Saarland. All participants provided written informed consent.

\section{Dementia assessment}

During the 14- and 17-year follow-up, the GPs of 8,353 ESTHER study participants $(84 \%)$ could still be contacted and were asked to provide information relating to a diagnosis of dementia since enrollment and to send the corresponding medical records, if available. GPs of participants who had dropped out of the study or had died were also contacted. In total, GPs of $n=6,357$ participants provided dementia diagnosis information. Dementia diagnoses were made in community settings by different medical doctors according to the International Classification of Diseases (ICD-10), the official classification for the encoding of medical diagnoses in Germany, and with heterogeneous diagnostic procedures as could be inferred from the available medical records.

The present dataset included 507 controls (participants that remained without dementia diagnosis throughout follow-up) chosen at random and 261 dementia cases (dementia diagnosis occurring between baseline and the 17-year follow-up), as previously described. ${ }^{30}$ Among the dementia cases there were $n=163$ participants with a diagnosis of the clinical syndrome of $A D$ ( $A D$ dementia), thereof $n=18$ with an additional diagnosis of vascular dementia $(\mathrm{VaD})$ or mixed dementia, and $n=83$ with a diagnosis of $\mathrm{VaD}$, thereof 17 with an additional diagnosis of $\mathrm{AD}$ dementia or mixed dementia. For $n=15$ only a diagnosis of mixed dementia was reported. However, a close examination of the available medical records revealed that comorbidity of neurodegenerative and cerebrovascular pathologies were highly prevalent among all 
medRxiv preprint doi: https://doi.org/10.1101/2022.01.16.22269370; this version posted January 16, 2022. The copyright holder for this preprint (which was not certified by peer review) is the author/funder, who has granted medRxiv a license to display the preprint in All rights reserved. No reuse allowed without permission.

dementia cases. In light of results of clinical-pathological studies performed among population-based cohorts showing that vascular pathologies are the most prevalent pathologies among demented patients, ${ }^{31-32}$ and based on the observation that pure $A D$ pathology is very rare,,$^{33}$ we hence assume that in the ESTHER cohort even in cases where a specific dementia type is reported as primary diagnosis, mixed pathologies were likely to be present in the great majority of dementia cases. In the following, we will use the term dementia risk to indicate the risk of a clinical diagnosis of dementia reflecting a composite endpoint including $A D, V a D$, and mixed dementia, with $\mathrm{AD}$ dementia and $\mathrm{VaD}$ indicating predominance of clinical symptoms closer to neurodegenerative or vascular pathologies, respectively.

\section{Laboratory measurements}

Markers of neurodegeneration. GFAP, NfL, and p-tau181 were measured in a single batch in lithium-heparin plasma of baseline samples at the Center for Protein Diagnostics (PRODI) of Bochum University (Germany) using the single molecule array (Simoa) Neurology 4-Plex E Advantage Kit and Simoa pTau-181 Advantage V2 Kit (Quanterix, USA) on a HD-X Analyzer as per manufacturer's instructions. A detailed description of the measurements can be found in a previous work of our group. ${ }^{30}$ All three markers were grouped in a joint category related to neurodegeneration because their elevation is indicative of underlying neurodegenerative dementias.

Total cholesterol. Cholesterol levels were determined in all ESTHER participants at baseline, with samples taken at the same time as the plasma used to measure markers of neurodegeneration. Cholesterol concentrations were measured in serum using a timed-endpoint method by which cholesterol esterase hydrolyzes esters to free cholesterol (Beckman Coulter SYNCHRON System(s)). The measurements 
medRxiv preprint doi: https://doi.org/10.1101/2022.01.16.22269370; this version posted January 16, 2022. The copyright holder for this preprint (which was not certified by peer review) is the author/funder, who has granted medRxiv a license to display the preprint in All rights reserved. No reuse allowed without permission.

were performed in the Labor of the University Clinic Heidelberg, Germany. Hypercholesterolemia was defined as TC $\geq 240 \mathrm{mg} / \mathrm{dL} .{ }^{34-35}$

$\underline{A P O E \text { genotype. }}$ ealleles were determined based on allelic combinations of single nucleotide polymorphisms (SNP) rs7412 and rs429358 using TaqMan SNP genotyping assays. Genotypes were analyzed in an endpoint allelic discrimination read using a PRISM 7000 Sequence detection system (Applied Biosystems). In some cases with missing values $(n=38)$ the APOE genotype could be determined based on APOE SNP results from GWAS data. Participants were divided into carriers of the $\varepsilon 4$ allele $(\varepsilon 2 / \varepsilon 4, \varepsilon 3 / \varepsilon 4, \varepsilon 4 / \varepsilon 4)$ and non-carriers $(\varepsilon 2 / \varepsilon 2, \varepsilon 2 / \varepsilon 3, \varepsilon 3 / \varepsilon 3)$.

\section{Cardiovascular diseases (CVD) and sociodemographic data}

CVD used for the analyses were diagnosed either at or prior to baseline and defined as combined category including stroke, myocardial infarction, coronary artery disease, or coronary revascularization. Age, sex, and educational level (less, equal to, or higher than 9 years of school education) were collected through the selfadministered questionnaire administered at baseline.

\section{Statistical analysis}

Main baseline characteristics of the included ESTHER cases and controls were described for the whole population and according to levels of TC. Multivariate logistic regression models adjusted for age, sex, educational level, TC, and APOE $\varepsilon 4$ genotype were estimated for the outcomes dementia, AD dementia, and VaD. Values of markers of neurodegeneration were divided into quartiles $(Q)$, and odds ratios $(\mathrm{OR})$ with $95 \%$ confidence intervals $(\mathrm{Cl})$ were calculated for the highest quartile $\left(\mathrm{Q}_{4}\right)$ compared with the other three quartiles $\left(\mathrm{Q}_{1-3}\right)$, serving as the reference group. All regression models were run for the overall sample and, separately, by levels of TC (high: $\geq 240 \mathrm{mg} / \mathrm{dL}$; low $<240 \mathrm{mg} / \mathrm{dL}$ ). ${ }^{34-35}$ Additional regression models adjusted for 
medRxiv preprint doi: https://doi.org/10.1101/2022.01.16.22269370; this version posted January 16, 2022. The copyright holder for this preprint (which was not certified by peer review) is the author/funder, who has granted medRxiv a license to display the preprint in All rights reserved. No reuse allowed without permission.

age, sex, educational level, and TC were performed stratified by APOE \&4 genotype (carriers/non-carriers) and by CVD. To test for significant differences in associations of the biomarkers with dementia risk between TC and CVD subgroups, interaction terms for the respective biomarker with TC or CVD, respectively, were added to all models.

Dose-response analyses using restricted cubic spline functions (RCS) with knots at the $5^{\text {th }}, 35^{\text {th }}, 65^{\text {th }}$, and $95^{\text {th }}$ percentiles were conducted. A receiver operating characteristic (ROC) curve was calculated in order to explore the discriminative power of the markers of neurodegeneration in addition to age, sex, educational level, and $A P O E$ \&4. RCS functions and ROC curves were derived separately in subgroups with high and low TC; the values of GFAP, NfL, and p-tau181 were inserted as continuous variables. For all three biomarkers, the distributions were moderately right skewed. However, since the data were reasonably close to a normal distribution and for better interpretability, we used the original values but performed sensitivity analyses with log-transformed values. All analyses were performed with the statistical software SAS®, version 9.4, Cary, NC, USA.

\section{Results}

In this nested case-control study, the majority of cases and controls was older than sixty years and a large majority had a low educational level (Table 1). In total, $n=94$ $(36 \%)$ cases and $n=194(38 \%)$ controls had high TC and both among cases and controls this percentage was higher among $A P O E \& 4$ carriers than among noncarriers (cases: $42 \%$ vs. $32 \%$, controls: $41 \%$ vs. $38 \%$ ). For all three markers of neurodegeneration, levels were higher among cases.

Results of regression analyses showed that the odds of a dementia diagnosis were much higher among participants with both high baseline levels of markers of 
medRxiv preprint doi: https://doi.org/10.1101/2022.01.16.22269370; this version posted January 16, 2022. The copyright holder for this preprint (which was not certified by peer review) is the author/funder, who has granted medRxiv a license to display the preprint in All rights reserved. No reuse allowed without permission.

neurodegeneration and high TC levels than among participants with low TC (Table 2). This pattern was particularly evident for GFAP and NfL, for which ORs among participants with high TC were 5.10 (Cl 2.45-10.60) and $2.96(\mathrm{Cl} 1.43-6.14)$, respectively. For comparison, the ORs among participants with low TC were 2.44 (Cl 1.47-4.07) and 1.15 ( $\mathrm{Cl} 0.69-1.92)$, respectively. Models including interaction terms yielded a statistically significant interaction between NfL and TC with respect to dementia risk $(p=0.037)$.

The additional stratification of the models by $A P O E \& 4$ genotype revealed particularly high odds of dementia, with an OR of $10.02(\mathrm{Cl} 3.57-28.15)$ among APOE $\varepsilon 4$ non-carriers with high GFAP and high TC, and an OR of 4.21 (Cl 1.15-15.40) among carriers with high NfL and high TC. While the interaction between GFAP and TC was statistically significant in the APOE $\varepsilon 4$ - subgroup $(p=0.012)$, the interaction between NfL and TC was statistically significant in the APOE $\varepsilon 4+\operatorname{subgroup~}(\mathrm{p}=$ 0.018). Interactions including p-tau181 were not statistically significant.

High levels of GFAP at baseline were also associated with 12-fold odds of dementia among participants with CVD, compared to roughly twofold odds among those free of CVD at baseline (Table 3). A similar pattern could not be observed for participants with high levels of NfL or p-tau181. By contrast, high levels of NfL and ptau181 were statistically significantly associated with dementia in the group without baseline CVD. Adding interaction terms to the models yielded statistically significant interactions between CVD and GFAP ( $p=0.010)$ and between CVD and $p$-tau181 $(p=0.040)$. In regression models not including markers of neurodegeneration and adjusted for age, sex, educational level, and $A P O E \varepsilon 4$, neither hypercholesteremia nor prevalence of CVD at baseline were independently associated with increased odds of dementia (OR 0.95; Cl 0.66-1.37 and OR 1.04, Cl 0.69-1.57, respectively). 
medRxiv preprint doi: https://doi.org/10.1101/2022.01.16.22269370; this version posted January 16, 2022. The copyright holder for this preprint (which was not certified by peer review) is the author/funder, who has granted medRxiv a license to display the preprint in All rights reserved. No reuse allowed without permission.

Regarding the type of dementia for GFAP the odds for VaD were higher among $A P O E \& 4$ carriers than among non-carriers, while the odds for $A D$ dementia were higher among non-carriers than carriers, particularly in the presence of high TC (Supplemental Table 1). For NfL, an opposite pattern could be observed in the presence of high TC (Supplemental Table 2). For p-tau181, associations with VaD were stronger among $A P O E \& 4$ carriers than among non-carriers and in the presence of high TC. (Supplemental Table 3).

Restricted cubic spline curves indicated a steadily increasing dose-response association between higher GFAP levels and dementia among participants with TC $\geq 240 \mathrm{mg} / \mathrm{dL}$ (Figure 1). For the other markers, dementia risk seemed to increase more strongly in participants with high TC levels, but leveled off with higher biomarker levels or even showed a tendency to decrease at higher NfL levels. ROC curve analyses for dementia also showed that GFAP was the marker with the strongest discriminative ability in this cohort. Specifically, the area under the ROC curve (AUC) increased from $0.811(95 \% \mathrm{Cl} 0.758-0.864)$ for the main model to $0.841(0.791-0.891)$ after the inclusion of GFAP in the group of participants with high TC and from 0.768 $(95 \% \mathrm{Cl} 0.724-0.813)$ to $0.780(95 \% \mathrm{Cl} 0.737-0.824)$ in the group with low TC (Figure 2). The inclusion of NfL and p-tau181 to the main model increased the AUC only marginally. Sensitivity analyses performed with the log transformed values yielded results largely similar to those obtained with the original values.

\section{Discussion}

In this study, we examined associations of markers of neurodegeneration with dementia risk in a population with a high prevalence of mixed pathology and found that the strength of the associations dramatically changed depending on levels of TC and on $A P O E \& 4$ genotype. We also found that the association of GFAP, but not of 
medRxiv preprint doi: https://doi.org/10.1101/2022.01.16.22269370; this version posted January 16, 2022. The copyright holder for this preprint (which was not certified by peer review) is the author/funder, who has granted medRxiv a license to display the preprint in All rights reserved. No reuse allowed without permission.

NfL and p-tau181, with dementia risk was strongly augmented among people with CVD, independently of hypercholesterolemia. Additionally, the findings showed that GFAP and, to a lesser extent, NfL are more promising than p-tau181 for predicting dementia risk in the older general population with high cardiovascular burden.

Since hypercholesterolemia and $A P O E \& 4$ are crucial for cardiovascular health, ${ }^{23,35}$ these findings strongly support a vascular link between brain and body health. However, they also suggest that high TC and CVD as risk factors for dementia might become evident only in synergism with other markers or pathologies and, possibly, with genetic information relating to $A P O E \varepsilon 4$ status. This observation would explain the inconsistent findings reported in the literature relating to associations of hypercholesterolemia, CVD, and dementia. ${ }^{36-38}$

The link between vascular pathology and dementia is supported by the relationship between neural activity and cerebral blood flow (neurovascular coupling). ${ }^{3,39-40}$ Neurovascular coupling is a multidimensional process involving several agents and signals, ${ }^{3}$ with astrocytes playing an instrumental role. ${ }^{41-42}$ This might contribute to explaining why GFAP, a marker of activated astrocytes, was the strongest predictor of dementia in this cohort and why the strength of the association of GFAP with dementia risk was mostly increased in an unhealthy vascular milieu. Furthermore, although brain and peripheral cholesterol are separated by the bloodbrain barrier (BBB) and are regulated independently, they can be interconnected and both brain and peripheral cholesterol dysfunction can contribute to dementia. ${ }^{21,43}$ Hence, high GFAP levels might also point to a possible dysregulation in brain cholesterol produced by astrocytes, which might have synergistic effects with peripheral cholesterol for dementia development. Furthermore astrocytes also 
medRxiv preprint doi: https://doi.org/10.1101/2022.01.16.22269370; this version posted January 16, 2022. The copyright holder for this preprint (which was not certified by peer review) is the author/funder, who has granted medRxiv a license to display the preprint in All rights reserved. No reuse allowed without permission.

contribute to the maintenance of the BBB and high GFAP levels might indicate a malfunctioning of the BBB.

In a recent study, GFAP was not associated with $A P O E \varepsilon 4$, but GFAP levels were highest among $A P O E \& 4$ non-carriers with $A D$ pathology. ${ }^{13}$ The focus on $T C$ in this study allowed us to expand those observations and show that dementia and AD dementia risk was much higher in non-carriers with high TC than in carriers, pointing to a possible synergism between high GFAP and non-carrier status for dementia and $\mathrm{AD}$ dementia. For $\mathrm{VaD}$, an opposite pattern could be observed, but due to the small number of participants with $\mathrm{VaD}$, the results relating to this subgroup should be interpreted with caution.

$\mathrm{NfL}$ is a blood marker of axonal damage and has been found elevated both in dementia, including AD, and in cerebrovascular disease $\mathrm{e}^{20,44}$, and high NfL levels have been associated with an increased risk of all-cause dementia, $A D$, and $A D$ progression. ${ }^{12,44-45}$ Furthermore, it has been shown that an elevated vascular risk factor burden might synergistically interact with AD pathophysiology contributing to longitudinal increases in plasma NfL and cognitive decline. ${ }^{46}$ Our results expand these previous observations by pointing to $\mathrm{NfL}$ as a marker for dementia with mixed pathology, especially among APOE \&4 carriers with hypercholesterolemia.

Blood p-tau181 has been shown to be a marker associated with progressive AD-related neurodegeneration and capable of distinguishing $A D$ from $V a D$ and other neurodegenerative disorders in previous research. ${ }^{12,16}$ These results have been found in well-characterized cohorts with evidence of AD pathology in the brain. In our community-based cohort including participants with mixed pathology, p-tau181 was weakly associated with dementia and the results were not statistically significant. The presence of hypercholesterolemia had a marginal impact on the strength of the association, except for $\mathrm{VaD}$, which might support previous observations showing 
medRxiv preprint doi: https://doi.org/10.1101/2022.01.16.22269370; this version posted January 16, 2022. The copyright holder for this preprint (which was not certified by peer review) is the author/funder, who has granted medRxiv a license to display the preprint in All rights reserved. No reuse allowed without permission.

associations of accumulation of tau pathology with vascular cognitive impairment. ${ }^{47}$ Our findings point to the need to further examine the role of vascular pathologies and vascular risk factors in the association between p-tau181 with dementia.

The findings of the present study strongly support results of our previous study showing that hypercholesterolemia and CVD changed the association of $A P O E \varepsilon 4$ with cognitive function in two independent cohorts ${ }^{11}$ and provide observational evidence to clinicopathological data from population-based cohorts suggesting an incremental risk of dementia in patients with concomitant vascular and neurodegenerative pathologies compared with patients with only AD-type pathology. ${ }^{31}$ Our findings contribute to explaining this increased dementia risk by suggesting a mechanism involving genetic predisposition and a crosstalk between central and peripheral cholesterol metabolism, possibly driven by the permeabilization of the BBB. ${ }^{21}$ Several factors would contribute to permeabilization of the BBB in this cohort and they include micro- and macroangiopathies, vascular risk factors, inflammatory processes driven by high peripheral cholesterol, and astrocyte damage. In turn, the permeabilization of the BBB could facilitate the release of GFAP in the peripheral circulation. ${ }^{48}$ Another contributing factor for the increased dementia risk is the possible over-production of astrocyte-derived cholesterol driven by abnormal activation and proliferation of astrocytes, which in turn leads to increased AD-like pathology, as shown in lab mice. ${ }^{48}$ These mechanisms involving CVD and dysregulation of central and peripheral cholesterol would also explain why high GFAP levels as a marker for dementia works exceptionally well in this sample with mixed pathologies and has a stronger association with $\mathrm{VaD}$ than with $\mathrm{AD}$ dementia in this unselected population. The complexity and the multifariousness of the role of cholesterol and CVD in dementia also contribute to explaining the inconsistent finding in the literature relating to CVD and hypercholesterolemia for dementia and suggest 
medRxiv preprint doi: https://doi.org/10.1101/2022.01.16.22269370; this version posted January 16, 2022. The copyright holder for this preprint (which was not certified by peer review) is the author/funder, who has granted medRxiv a license to display the preprint in All rights reserved. No reuse allowed without permission.

that blood levels of GFAP could serve both for assessment of dementia risk and for evaluating effects of dementia prevention strategies addressing hypercholesterolemia. Future studies performed both in human cohorts and in vitro will be crucial in understanding the biological mechanisms underpinning these novel observations.

The coeval measurements of TC and markers of neurodegeneration prevented a temporal exploration of the observed association and limited its interpretation. Other important limitations were the lack of brain biomarkers for ADpathology and the lack of standardization of dementia diagnoses. Nevertheless, the use of a population-based cohort with 17-year follow-up and high comorbidity of neurodegenerative and cerebrovascular disease reflecting the majority of dementia cases in community settings allowed the identification of GFAP, and to a less extent $\mathrm{NfL}$, as very strong markers for dementia, especially in a milieu with high circulating peripheral cholesterol.

Further studies shall expand such observations to subgroups with low- and high-density lipoprotein cholesterol in combination with other vascular risk factors, especially diabetes mellitus and hypertension and shall especially focus on comprehensive analyses relating to GFAP and mixed dementia in unselected cohorts.

\section{Conflict of interest:}

The authors have no conflicts of interest to disclose.

\section{Finding/support and role of funder/sponsor:}

The ESTHER study was funded by grants from the Saarland State Ministry for Social Affairs, Health, Women and Family Affairs (Saarbrücken, Germany), the Baden- 
medRxiv preprint doi: https://doi.org/10.1101/2022.01.16.22269370; this version posted January 16, 2022. The copyright holder for this preprint (which was not certified by peer review) is the author/funder, who has granted medRxiv a license to display the preprint in All rights reserved. No reuse allowed without permission.

Württemberg State Ministry of Science, Research and Arts (Stuttgart, Germany), the Federal Ministry of Education and Research (Berlin, Germany) and the Federal Ministry of Family Affairs, Senior Citizens, Women and Youth (Berlin, Germany). UM is supported by the Marga and Walter Boll Foundation, Kerpen, Germany. None of the funding sources had a role in the conduct of the study, in the analysis or interpretation of the data, in the writing of this manuscript or in the decision to submit it for publication.

\section{References}

1. Moscoso A, Rey-Bretal D, Silva-Rodriguez J, Grothe M, Schöll M, Aguiar P. Association of white matter hyperintensities with sub-treshold amyloid accumulation. Alzheimer's Dement 2020; 16(Suppl.5):e045902

2. Pase MP, Satizabal Cl, Seshadri S. Role of improved vascular health in the declining incidence of dementia. Stroke 2017; 48 STROKEAHA.

117.013369-2020. Doi:10.1161/STROKEAHA.

3. ladecola C. The neurovascular unit coming of age: a journey through neurovascular coupling in health and disease. Neuron 2017; 96: 17-42.

4. Iturria-Medina $Y$, Sotero RC, Toussaint PJ, Mateos-Pérez JM, Evans AC \& The Alzheimer's Disease Neuroimaging Initiative. Early role of vascular dysregulation on late-onset Alzheimer's disease based on multifactorial data-driven analysis. Nat Comm 2016; 7:11934.

5. Jackman K, ladecola C. Neurovascular regulation in the ischemic brain. ARS 2015; 22:149-160.

6. Livingston G, Huntley J, Sommerland A, et al. Dementia prevention, intervention, and care: 2020 report of the Lancet Commission. Lancet 2020; 396 (10248):413-446. 
medRxiv preprint doi: https://doi.org/10.1101/2022.01.16.22269370; this version posted January 16, 2022. The copyright holder for this preprint (which was not certified by peer review) is the author/funder, who has granted medRxiv a license to display the preprint in All rights reserved. No reuse allowed without permission.

7. Fiford CM, Nicholas JM, Biessels GJ, Lane CA, Cardoso MJ, Barnes J. High blood pressure predicts hippocampa atrophy rate in cognitively impaired elders. Alzheimer's Dement 2020; 12:e12035.

8. McGrath ER, Beiser AS, DeCarli C, Plourde KL, Vasan RS, Greenberg SM et al. Blood pressure from mid- to life and risk of incident dementia. Neurology 2017; 89(24):2447-2454.

9. Biessels GJ, Despa, F. Cognitive decline and dementia in diabetes: mechanisms and clinical implications. Nat Rev Endocrinol 2018; 14(10):591-604.

10. Pugazhenthi S, Qin L, Reddy PH. Common neurodegenerative pathways in obesity, diabetes, and Alzheimer's disease. Biochim Biophys Acta Mol Basis of Dis 2017; 1863: 1037-1045.

11.Perna L, Mons U, Rujescu D, Kliegel M, Brenner H. Apolipoprotein E e4 and cognitive function; A modifiable association. Results from two independent cohort studies. Dement Geriatr Cogn Disord 2016; 41: 35-45.

12. Moscoso A, Grothe MJ, Ashton NJ, et al. Longitudinal associations of blood phosphorylated Tau181 and neurofilament light chain with neurodegeneration in Alzheimer disease. JAMA Neurol 2021; 78(4):396406.

13. Chatterjee P, Pedrini S, Stoops E, et al. Plasma fibrillary acidic protein is elevated in cognitively normal older adults at risk of Alzheimer's disease. Transl Psychiatry 2021; 11:27.

14. Thijssen $E H$, La Joie $R$, Wolf $A$, et al. Diagnostic value of plasma phosphorylated tau 181 in Alzheimer's disease and frontotemporal lobar degeneration. Nat Med 2020; 26:387-397. 
medRxiv preprint doi: https://doi.org/10.1101/2022.01.16.22269370; this version posted January 16, 2022. The copyright holder for this preprint (which was not certified by peer review) is the author/funder, who has granted medRxiv a license to display the preprint in All rights reserved. No reuse allowed without permission.

15. Elahi FM, Casaletto KB, La Joie R et al. Plasma biomaerkers of astrocytic and neuronal dysfunction in early-and late-onset Alzheimer's disease.

Alzheimers Dement 2020; 16(4): 681-695.

16. Karikari TK, Pascoal TA, Ashtonn NJ, Janelidze S, Benedet AL, Rodriguez JL et al. Blood phosphorylated tau 181 as a biomarker for Alzheimer's disease: a diagnostic performance and prediction modelling study using data from four perspective cohorts. Lancet Neurol 2020; 19(5):422-433.

17. Ebner F, Moseby-Knappe M, Mattsson-Carlgren N, et al. Serum GFAP and $\mathrm{UCH}-\mathrm{L} 1$ for the prefdction of neurological outcome in comatose cardiac arrest. Resuscitation 2020; 154:61-68.

18. Uphaus T, Bittner S, Gröschel S, et al. NfL (Neurofilament light chain) levels as a predictive marker for long-term outcome after ischemic stroke. Stroke 2019; 50(11):3077-3084.

19. Korley FK, Goldstick J, Mastali M. et al. Serum NfL (Neurofilament Light Chain) levels and incident stroke in adults with diabetes mellitus. Stroke 2019; 50(7): 1669-1675.

20. Gaetani L, Blennow K, Calabresi P, Di Filippo M, Parnetti L, Zetterberg H. Neurofilament light chain as a biomarker in neurological disorders. J Neurol Neurosurg Psychiatry 2019; 90 (8): 870-881.

21. Gliozzi M, Musolino V, Bosco F, et al. Cholesterol homeostasis: Researching a dialogue between the brain and peripheral tissues. Pharmacological Research 2021; 163.

22. Varma VR, Wang $Y$, An $Y$, et al. Bile acid synthesis, modulation, and dementia: A metabolomic, transcriptomic, and pharmacoepidemiologic study. Plos Med 2021; 18 (5):e1003615. 
medRxiv preprint doi: https://doi.org/10.1101/2022.01.16.22269370; this version posted January 16, 2022. The copyright holder for this preprint (which was not certified by peer review) is the author/funder, who has granted medRxiv a license to display the preprint in All rights reserved. No reuse allowed without permission.

23. Mahley RW. Apolipoprotein E: from cardiovascular disease to neurodegenerative disorders. J Mol Med (Berl) 2016; 94:739-746

24. Koizumi K, Hattori Y, Ji Ahn, et al. Apoe4 disrupts neurovascular regulation and undermines white matter integrity and cognitive function. Nat Commun 9:3816.

25. Rohn TT. Is apolipoprotien E4 an important risk factor for vascular dementia? Int J Clin Exp Pathol 2014; 7(7): 3504-3511.

26. Mooldijk SS, Licher S, Wolters FJ. Characterizing demographic, racial, and geographic diversity in dementia research A systematic review. JAMA Neurol 2021; doi:10.1001/jamaneurol.2021.2943.

27. Elliot CL, Ryan L, Silverberg N. Building inclusive and open Alzheimer disease and Alzheimer disease-related dementias research programs. JAMA Neurol 2021; doi:10.1001/jamaneurol.2021.2941.

28. Löw M, Stegmaier C, Ziegler H, Rothenbacher D, Brenner H. [Epidemiological investigations of the chances of preventing, recognizing early and optimally treating chronic diseases in an elderly population (ESTHER study)]. Deutsche medizinische Wochenschrift (1946). 2004;129:2643-7.

29. Breitling LP, Perna L, Müller H, Raum E, Kliegel M, Brenner H. Vitamin D and cognitive functioning in the elderly population in Germany. Exp Gerontol 2012; 47(1):122-127.

30. Stocker H, Beyer L, Perna L, et al. Association of plasma biomarkers, Ptau181, glial fibrillary acidic protein, and neurofilament light, with intermediate and long-term clinical Alzheimer's disease risk: Results from a prospective cohort followed over 17 years. Alzheimer's Dement 2022; in press. 
medRxiv preprint doi: https://doi.org/10.1101/2022.01.16.22269370; this version posted January 16, 2022. The copyright holder for this preprint (which was not certified by peer review) is the author/funder, who has granted medRxiv a license to display the preprint in All rights reserved. No reuse allowed without permission.

31. Azarpazhooh MR, Avan A, Cipriano LE, Munoz DG, Sposato LA, Hachinski V. Concomitant vascular and neurodegenerative pathologies double the risk of dementia. Alzheimers Dement 2018; 14:148-156.

32. Kapasi A, DeCarli C, Schneider JA. Impact of multiple pathologies on the threshold for clinically overt dementia. Acta Neuropathol 2017; 134(2):171186.

33. Bennett DA, Buchman AS, Boyle P, Barnes LL, Wilson RS, Schneider JA. Religious orders study and Rush memory and aging project. J Alzheimers Dis 2018; 64 (s1):S161-S189.

34. Grundy SM, Stone NJ, Bailey AL, et al. AHA/ACC/AACVPR/AAPA/ABC/ACPM/ADA/AGS/APhA/ASPC/NLA/PCNA Guideline on the management of blood cholesterol: A report of the American College of Cardiology/American Heart Association Task Force on Clinical Practice Guidelines. Circulation 2019; 139(25):e1082-e1143.

35. Benjamin EJ. Blaha. MJ, Chiuve SE, et al. Heart disease and stroke statistics-2017 update: a report from the American Heart Association. Circulation. 2017; 135 (10): e146-e603.

36. Hoevenaar-Blom MP, Richard E, Moll van Charant E, et al. Observational extension oft he preventioan of dementia by intensive vascular care (preDIVA) trial. JAMA Neurol doi:10.1001/jamaneurol.2021.3542

37. Pillai JA, Kou L, Bena J, Penn L, Leverenz JB. hypertension and hypercholesterolemia modify dementia risk in relation to APOEe4 status. $J$ Alzheimer Dis 2021; 81(4):1493-1504.

38. McFarlane O, Kędziora- Kornatowska. Cholesterol and dementia: A long and complicated relationship. Curr Aging Sci 2020; 13(1):42-51. 
medRxiv preprint doi: https://doi.org/10.1101/2022.01.16.22269370; this version posted January 16, 2022. The copyright holder for this preprint (which was not certified by peer review) is the author/funder, who has granted medRxiv a license to display the preprint in All rights reserved. No reuse allowed without permission.

39. Sweeney MD, Kisler K, Montagne A, et al. The role of brain vasculature in neurodegenerative disorders. Nat Neuroscience 2018; 21: 1318-1331.

40. de la Torre JC. Are major dementias triggered by poor blood flow to the brain? Theoretical considerations. J Alzheimers Dis. 2017; 57: 353-371.

41. Kim KJ, Ramiro Diaz J, Iddings JA. Vasculo-Neuronal Coupling:

Retrograde vascular communication to brain neurons. J Neurosci 2016; 36:12624-12639.

42. Muñoz MF, Puebla M, Figueroa XF. Control of the neurovascular coupling by nitric oxide-dependent regulation of $\mathrm{Ca}^{2+}$ signaling. Front Cell Neurosci 2015; 9:59.

43. Zhang J, Liu Q. Cholesterol metabolism and homeostasis in the brain. Protein Cell 2015; 6(4): 254-264.

44. de Wolf F, Ghanbari M, Licher S, et al. Plasma tau, neurofilament light chain and amyloid- $\beta$ levels and risk of dementia; a population-based cohort study. Brain 2020; 143(4):1220-1232.

45. Rauchmann BS, Schneider-Axmann T, Perneczky R, Alzheimer's Disease Neuroimaging Initiative (ADNI). J Neurol Neurosurg Psychiatry 2021 Jun 29:jnnp-2020-325537. doi: 10.1136/jnnp-2020-325537.

46. Ferrari-Souza JP, Brum WS, Haushild LA, et al. Vascular risk burden is a key player in the early progression of Alzheimer's disease medRxiv 2021.12.18.21267994; doi:https://doi.org/10.1101/2021.12.18.212 67994

47. Kim HJ, Park S, Cho H et al. Assessment of extent and role of tau in subcortical vascular cognitive impairment using 18F-AV1451 positron emission tomography imaging. JAMA Neurol 2018; 75: 999-1007. 
48. Benedet $\mathrm{AL}$, Milà-Alomà $\mathrm{M}$, Vrillon $\mathrm{A}$, et al. Differences between plasma and cerebrospinal fluid glial fibrillary acidic protein levels across the Alzheimer disease continuum. JAMA Neurol 2021; doi:10.1001/jamanneurol.2021.3671. Online ahead of print.

49. Wang $\mathrm{H}$, Kulas JA, Wang C, Holtzmann DM, Ferris HA, Hansen SB. Regulation of beta-amyloid production in neurons by astrocyte-derived cholesterol. Proc Natl Acad Sci USA 2021; 118(33):e2102191118. 
medRxiv preprint doi: https://doi.org/10.1101/2022.01.16.22269370; this version posted January 16, 2022. The copyright holder for this preprint (which was not certified by peer review) is the author/funder, who has granted medRxiv a license to display the preprint in perpetuity.

All rights reserved. No reuse allowed without permission.

Table 1 Main characteristics of the study population

\begin{tabular}{|c|c|c|c|c|c|c|}
\hline \multirow[b]{2}{*}{$\begin{array}{l}\text { ESTHER study } \\
(\mathrm{n}=768)\end{array}$} & \multicolumn{3}{|c|}{ Cases } & \multicolumn{3}{|c|}{ Controls } \\
\hline & $\begin{array}{l}\text { overall } \\
\mathrm{n}=\mathbf{2 6 1}\end{array}$ & $\begin{array}{c}\text { high TC }^{\text {a }} \\
n=94\end{array}$ & $\begin{array}{c}\text { low TC } \\
n=167\end{array}$ & $\begin{array}{l}\text { overall } \\
n=507\end{array}$ & $\begin{array}{c}\text { high TC }^{a} \\
n=194\end{array}$ & $\begin{array}{c}\operatorname{low}_{n=312}{ }^{b} \\
\end{array}$ \\
\hline & n (\%) & n (\%) & n (\%) & n (\%) & n (\%) & n (\%) \\
\hline \multicolumn{7}{|l|}{ Age groups } \\
\hline $50-59$ & $20(7.7)$ & $8(8.5)$ & $12(7.2)$ & $202(39.8)$ & $79(40.7)$ & $123(39.4)$ \\
\hline $60-70$ & $152(58.2)$ & $54(57.5)$ & $98(58.7)$ & $258(50.9)$ & $101(52.1)$ & $156(50.0)$ \\
\hline $71-75$ & $89(34.1)$ & $32(34.0)$ & $57(34.1)$ & $47(9.3)$ & $14(7.2)$ & $33(10.6)$ \\
\hline \multicolumn{7}{|l|}{ Sex } \\
\hline women & $151(57.9)$ & $64(68.1)$ & $87(52.1)$ & $278(54.8)$ & 120 (61.9) & $158(50.6)$ \\
\hline men & $110(42.1)$ & $30(31.9)$ & $80(47.9)$ & $229(45.2)$ & $74(38.1)$ & $154(49.4)$ \\
\hline \multicolumn{7}{|c|}{ Educational level } \\
\hline low $^{c}$ & $214(82.0)$ & $75(79.8)$ & 139 (83.2) & $394(77.7)$ & $156(80.4)$ & 238 (76.3) \\
\hline high d & $37(14.2)$ & $15(16.0)$ & $22(13.2)$ & $102(20.1)$ & 34 (17.5) & $67(21.5)$ \\
\hline missing values & $10(3.8)$ & $4(4.3)$ & $6(3.6)$ & $11(2.2)$ & $4(2.1)$ & $7(2.2)$ \\
\hline \multicolumn{7}{|l|}{ APOE $\varepsilon 4$} \\
\hline carriers $^{e}$ & $103(39.5)$ & $43(45.7)$ & $60(35.9)$ & $131(25.8)$ & $54(27.8)$ & $77(24.7)$ \\
\hline non-carriers ${ }^{f}$ & $143(54.8)$ & $46(48.9)$ & $97(58.1)$ & $364(71.8)$ & $137(70.6)$ & $226(72.4)$ \\
\hline missing values & $15(5.8)$ & $5(5.3)$ & $10(6.0)$ & $12(2.4)$ & $3(1.6)$ & $9(2.9)$ \\
\hline \multicolumn{7}{|l|}{ CVD $g$} \\
\hline yes & $76(29.1)$ & $19(20.2)$ & $57(34.1)$ & $101(19.9)$ & $32(16.5)$ & $69(22.1)$ \\
\hline \multirow[t]{2}{*}{ no } & 185 (70.9) & $75(79.8)$ & 110 (65.9) & $406(80.1)$ & 162 (83.5) & 243 (77.9) \\
\hline & mean (SD) & mean (SD) & mean (SD) & mean (SD) & mean (SD) & Mean (SD) \\
\hline GFAP & $133.2(78.2)$ & $146.0(99.1)$ & $126.0(62.6)$ & $87.0(46.7)$ & $83.4(40.8)$ & $89.3(50.0)$ \\
\hline NfL & $22.8(13.4)$ & $24.1(14.8)$ & $22.1(12.6)$ & $15.8(8.4)$ & $15.8(9.9)$ & $15.8(7.4)$ \\
\hline P-tau181 & $2.1(1.5)$ & $2.3(1.5)$ & $2.1(1.5)$ & $1.7(1.2)$ & $1.7(1.5)$ & $1.7(1.0)$ \\
\hline
\end{tabular}

TC, total cholesterol; SD, standard deviation; APOE, Apolipoprotein E; GFAP, Glial Fibrillary Acidic

Protein; NfL, Neurofilament light; p-tau181, tau phosphorylated at threonine 181.
a) $\mathrm{TC} \geq 240 \mathrm{mg} / \mathrm{dL}$
b) $\mathrm{TC}<240 \mathrm{mg} / \mathrm{dL}$
c) $\leq 9$ years of school education
d) $>9$ years of school education
e) participants carrying $A P O E \varepsilon 4$ genotype $(\varepsilon 2 \varepsilon 4$, $\varepsilon 3 \varepsilon 4$, $\varepsilon 4 \varepsilon 4)$
f) participants not carrying $A P O E \varepsilon 4$ genotype $(\varepsilon 2 \varepsilon 2, \varepsilon 3 \varepsilon 2, \varepsilon 3 \varepsilon 3)$
g) CVD was defined as combined endpoint of stroke, or myocardial infarction,
or coronary artery disease, or revascularization of coronary arteries, or pulmonary embolism. 
medRxiv preprint doi: https://doi.org/10.1101/2022.01.16.22269370; this version posted January 16, 2022. The copyright holder for this preprint (which was not certified by peer review) is the author/funder, who has granted medRxiv a license to display the preprint in perpetuity.

All rights reserved. No reuse allowed without permission.

Table 2 Associations of high ${ }^{\mathrm{a}}$ GFAP, NfL, and p-tau181 with dementia risk by total cholesterol and APOE \&4 status (ESTHER cohort study 2000-2017)

\begin{tabular}{|c|c|c|c|}
\hline & Overall & High TC $^{\text {b }}$ & Low TC ${ }^{c}$ \\
\hline $\begin{array}{l}\text { General population } \\
\text { ESTHER study } \\
(\mathrm{n}=768)\end{array}$ & $\begin{array}{l}\text { Odds ratio } \\
\text { (95\%Cl; } \\
\text { n= cases })\end{array}$ & $\begin{array}{l}\text { Odds ratio } \\
\text { (95\%Cl; } \\
\text { n= cases })\end{array}$ & $\begin{array}{l}\text { Odds ratio } \\
\text { (95\% } \mathrm{Cl} ; \\
\mathrm{n}=\text { cases })\end{array}$ \\
\hline \multicolumn{4}{|c|}{ Glial Fibrillary Acidic Protein } \\
\hline Overall & $\begin{array}{c}3.08 \\
(2.04-4.66) \\
(n=261)\end{array}$ & $\begin{array}{c}5.10 \\
(2.45-10.60) \\
(n=94)\end{array}$ & $\begin{array}{c}2.44 \\
(1.47-4.07) \\
(n=167)\end{array}$ \\
\hline$A P O E \varepsilon 4+^{d}$ & $\begin{array}{c}3.13 \\
(1.63-6.04) \\
(n=103)\end{array}$ & $\begin{array}{c}2.40 \\
(0.82-7.01) \\
(n=43)\end{array}$ & $\begin{array}{c}3.90 \\
(1.67-9.13) \\
(n=60)\end{array}$ \\
\hline$A P O E \varepsilon 4-{ }^{\mathrm{e}}$ & $\begin{array}{c}3.41 \\
(1.98-5.88) \\
(n=143)\end{array}$ & $\begin{array}{c}10.02 \\
(3.57-28.15) \\
(n=46)\end{array}$ & $\begin{array}{c}2.05 \\
(1.06-3.97) \\
(n=97)\end{array}$ \\
\hline \multicolumn{4}{|l|}{ Neurofilament light } \\
\hline Overall & $\begin{array}{c}1.57 \\
(1.04-2.38) \\
(n=261)\end{array}$ & $\begin{array}{c}2.96 \\
(1.43-6.14) \\
(n=94)\end{array}$ & $\begin{array}{c}1.15 \\
(0.69-1.92) \\
(n=167)\end{array}$ \\
\hline$A P O E \varepsilon 4+^{d}$ & $\begin{array}{c}1.30 \\
(0.62-2.70) \\
(n=103)\end{array}$ & $\begin{array}{c}4.21 \\
(1.15-15.40) \\
(n=43)\end{array}$ & $\begin{array}{c}0.67 \\
(0.26-1.74) \\
(n=60)\end{array}$ \\
\hline$A P O E \varepsilon 4-\mathrm{e}$ & $\begin{array}{c}1.82 \\
(1.10-3.01) \\
(n=143)\end{array}$ & $\begin{array}{c}2.42 \\
(0.98-5.97) \\
(n=46)\end{array}$ & $\begin{array}{c}1.55 \\
(0.84-2.85) \\
(97)\end{array}$ \\
\hline \multicolumn{4}{|l|}{ p-tau181 } \\
\hline Overall & $\begin{array}{c}1.29 \\
(0.86-1.93) \\
(n=261)\end{array}$ & $\begin{array}{c}1.51 \\
(0.77-2.98) \\
(n=94)\end{array}$ & $\begin{array}{c}1.19 \\
(0.72-1.97) \\
(n=167)\end{array}$ \\
\hline$A P O E \varepsilon 4+^{d}$ & $\begin{array}{c}0.99 \\
(0.52-1.91) \\
(n=103)\end{array}$ & $\begin{array}{c}1.10 \\
(0.38-3.18) \\
(n=43)\end{array}$ & $\begin{array}{c}0.97 \\
(0.41-2.26) \\
(n=60)\end{array}$ \\
\hline$A P O E \varepsilon 4-\mathrm{e}$ & $\begin{array}{c}1.67 \\
(1.00-2.79) \\
(n=143)\end{array}$ & $\begin{array}{c}2.02 \\
(0.83-4.94) \\
(n=46)\end{array}$ & $\begin{array}{c}1.55 \\
(0.82-2.93) \\
(n=97)\end{array}$ \\
\hline
\end{tabular}

GFAP, Glial Fibrillary Acidic Protein; NfL, Neurofilament light; p-tau181, tau phosphorylated at threonine 181; $A P O E$, Apolipoprotein E; TC, total cholesterol; $\mathrm{Cl}$, confidence interval.
a) $\geq$ quartile 4 (vs quartiles 1-3)
b) $\mathrm{TC} \geq 240 \mathrm{mg} / \mathrm{dL}$
c) $\mathrm{TC}<240 \mathrm{mg} / \mathrm{dL}$
d) participants carrying APOE $\varepsilon 4$ genotype $(\varepsilon 2 \varepsilon 4, \varepsilon 3 \varepsilon 4, \varepsilon 4 \varepsilon 4)$
e) participants not carrying $A P O E \varepsilon 4$ genotype $(\varepsilon 2 \varepsilon 2, \varepsilon 3 \varepsilon 2, \varepsilon 3 \varepsilon 3)$

All models were adjusted for age, sex, educational level, APOE $\varepsilon 4$ genotype, and TC. Subgroup analyses by TC were adjusted for age, sex, educational level, and $A P O E \varepsilon 4$. Subgroup analyses by TC and $A P O E \varepsilon 4$ genotype were adjusted for age, sex, and educational level. 
medRxiv preprint doi: https://doi.org/10.1101/2022.01.16.22269370; this version posted January 16, 2022. The copyright holder for this preprint (which was not certified by peer review) is the author/funder, who has granted medRxiv a license to display the preprint in perpetuity.

All rights reserved. No reuse allowed without permission.

Table 3 Associations of high ${ }^{\mathrm{a}}$ GFAP, NfL, and p-tau181 with dementia risk among participants with and without CVD (ESTHER cohort study 2000-2017)

\begin{tabular}{|c|c|c|c|}
\hline & $\begin{array}{l}\text { Glial Fibrillary } \\
\text { Acidic Protein }\end{array}$ & $\begin{array}{l}\text { Neurofilament } \\
\text { light }\end{array}$ & P-tau181 \\
\hline $\begin{array}{l}\text { ESTHER study } \\
(\mathrm{n}=768)\end{array}$ & $\begin{array}{l}\text { Odds ratio } \\
(95 \% \mathrm{Cl})\end{array}$ & $\begin{array}{l}\text { Odds ratio } \\
(95 \% \mathrm{Cl})\end{array}$ & $\begin{array}{l}\text { Odds ratio } \\
(95 \% \mathrm{Cl})\end{array}$ \\
\hline \multicolumn{4}{|c|}{$\begin{array}{l}\text { Subgroup with CVD } \\
(n=177)\end{array}$} \\
\hline $\begin{array}{l}\text { Dementia } \\
(n=76)\end{array}$ & $\begin{array}{c}12.47 \\
(4.43-35.06)\end{array}$ & $\begin{array}{c}1.26 \\
(0.59-2.69)\end{array}$ & $\begin{array}{c}0.72 \\
(0.31-1.66)\end{array}$ \\
\hline $\begin{array}{l}\text { Vascular dementia } \\
(n=31)\end{array}$ & $\begin{array}{c}6.12 \\
(2.10-17.82)\end{array}$ & $\begin{array}{c}1.41 \\
(0.54-3.67)\end{array}$ & $\begin{array}{c}1.64 \\
(0.60-4.50)\end{array}$ \\
\hline $\begin{array}{l}\text { Alzheimer's clinical } \\
\text { syndrome } \\
(n=39)\end{array}$ & $\begin{array}{c}3.63 \\
(1.45-9.13)\end{array}$ & $\begin{array}{c}0.80 \\
(0.32-1.96)\end{array}$ & $\begin{array}{c}0.68 \\
(0.26-1.76)\end{array}$ \\
\hline \multicolumn{4}{|c|}{$\begin{array}{l}\text { Subgroup without } C V D^{b} \\
(\mathrm{n}=591)\end{array}$} \\
\hline $\begin{array}{l}\text { Dementia } \\
(n=185)\end{array}$ & $\begin{array}{c}2.22 \\
(1.37-3.58)\end{array}$ & $\begin{array}{c}1.81 \\
(1.10-2.98)\end{array}$ & $\begin{array}{c}1.64 \\
(1.03-2.62)\end{array}$ \\
\hline $\begin{array}{l}\text { Vascular dementia } \\
(n=52)\end{array}$ & $\begin{array}{c}1.80 \\
(0.90-3.58)\end{array}$ & $\begin{array}{c}2.04 \\
1.02-4.06)\end{array}$ & $\begin{array}{c}1.95 \\
(1.01-3.76)\end{array}$ \\
\hline $\begin{array}{l}\text { Alzheimer's clinical } \\
\text { syndrome } \\
(n=124)\end{array}$ & $\begin{array}{c}1.78 \\
(1.07-2.94)\end{array}$ & $\begin{array}{c}1.34 \\
(0.79-2.28)\end{array}$ & $\begin{array}{c}1.54 \\
(0.94-2.52)\end{array}$ \\
\hline
\end{tabular}

GFAP, Glial Fibrillary Acidic Protein; NfL, Neurofilament light; p-tau181, tau phosphorylated at threonine 181; $\mathrm{CVD}$, cardiovascular disease; $\mathrm{Cl}$, confidence interval.

a) $\geq$ quartile 4 (vs quartiles $1-3$ )

b) CVD was defined as combined endpoint of stroke, or myocardial infarction, or coronary artery disease, or revascularization of coronary arteries, or pulmonary embolism.

All models were adjusted for age, sex, educational level, $A P O E \varepsilon 4$ genotype, and total cholesterol. 
medRxiv preprint doi: https://doi.org/10.1101/2022.01.16.22269370; this version posted January 16, 2022. The copyright holder for this preprint (which was not certified by peer review) is the author/funder, who has granted medRxiv a license to display the preprint in perpetuity.

All rights reserved. No reuse allowed without permission.

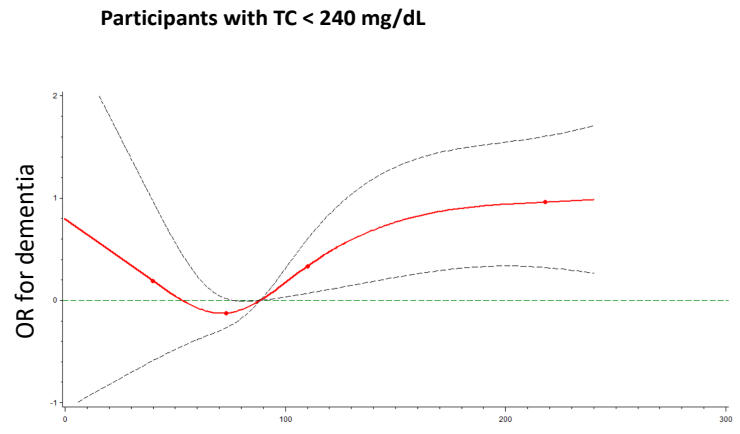

Glial fibrillary acidic protein levels
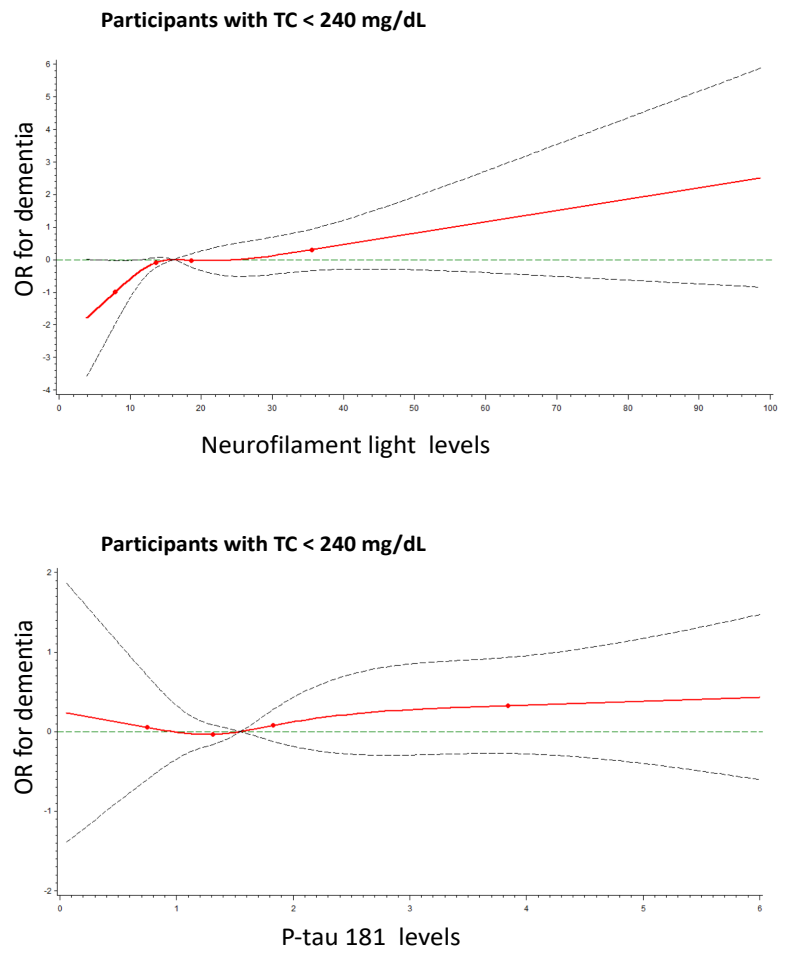

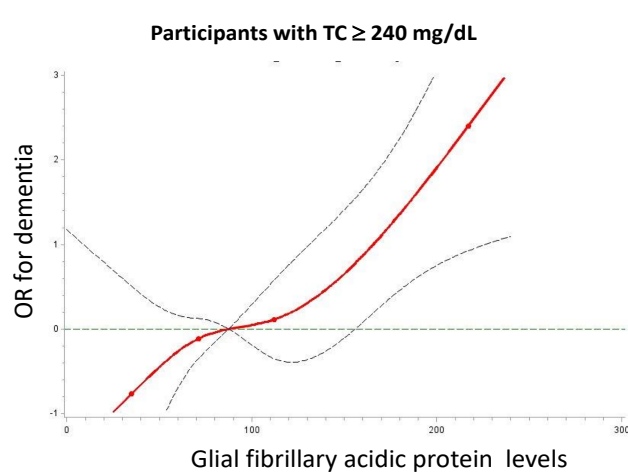

Participants with TC $\geq 240 \mathrm{mg} / \mathrm{dL}$
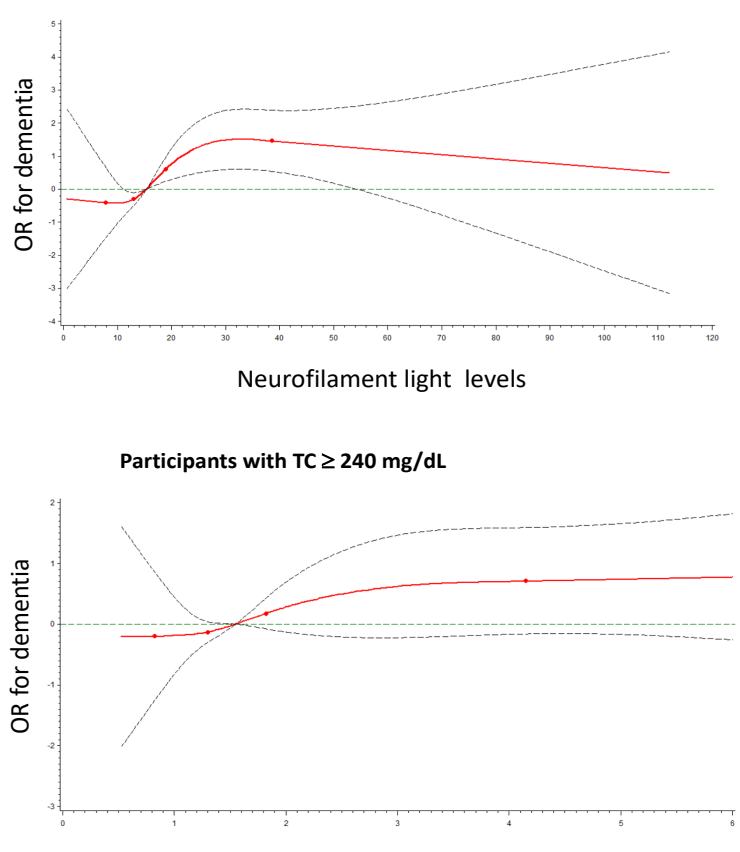

P-tau 181 levels

Figure 1. Dose-response associations of dementia by levels of total cholesterol; results of restricted cubic spline regression models.

Top row: Association of dementia with GFAP (Glial Fibrillary Acidic Protein) among participants with low (<240 mg/dL) and high ( $\geq 240 \mathrm{mg} / \mathrm{dL}$ ) total cholesterol (TC) levels. Middle row: Association of dementia with NfL (Neurofilament light) among participants with low (<240 mg/dL) and high ( $2240 \mathrm{mg} / \mathrm{dL}$ ) TC levels. Bottom row: Association of dementia with p-tau 181 (tau phosphorylated at threonine 181) among participants with low (<240 mg/dL) and high ( $\geq 240 \mathrm{mg} / \mathrm{dL}) \mathrm{TC}$ levels. Results of spline regression models adjusted for age, sex, educational level, and $A P O E \varepsilon 4$ polymorphism $(\varepsilon 2 \varepsilon 4, \varepsilon 3 \varepsilon 4, \varepsilon 4 \varepsilon 4$ vs $\varepsilon 2 \varepsilon 2$, $\varepsilon 3 \varepsilon 2$, $\varepsilon 3 \varepsilon 3)$. GFAP, NfL, and p-tau 181 were inserted in the models as continuous variables. Solid line: point estimates; dashed curved lines: $95 \%$ confidence interval limits; dashed horizontal line: reference line (odds ratio $=1$ ); dots: knots $\left(5^{\text {th }}, 35^{\text {th }}, 65^{\text {th }}\right.$, and $\left.95^{\text {th }}\right)$. 
medRxiv preprint doi: https://doi.org/10.1101/2022.01.16.22269370; this version posted January 16, 2022. The copyright holder for this preprint (which was not certified by peer review) is the author/funder, who has granted medRxiv a license to display the preprint in All rights reserved. No reuse allowed without permission.

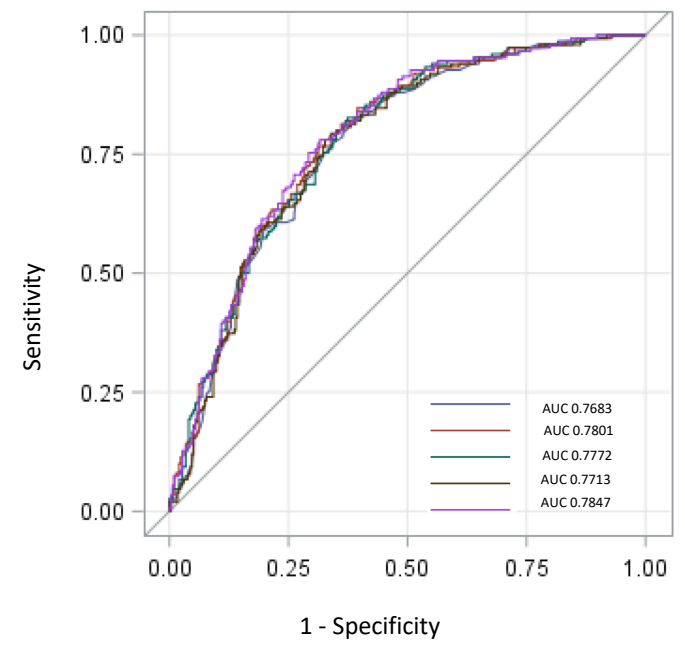

A

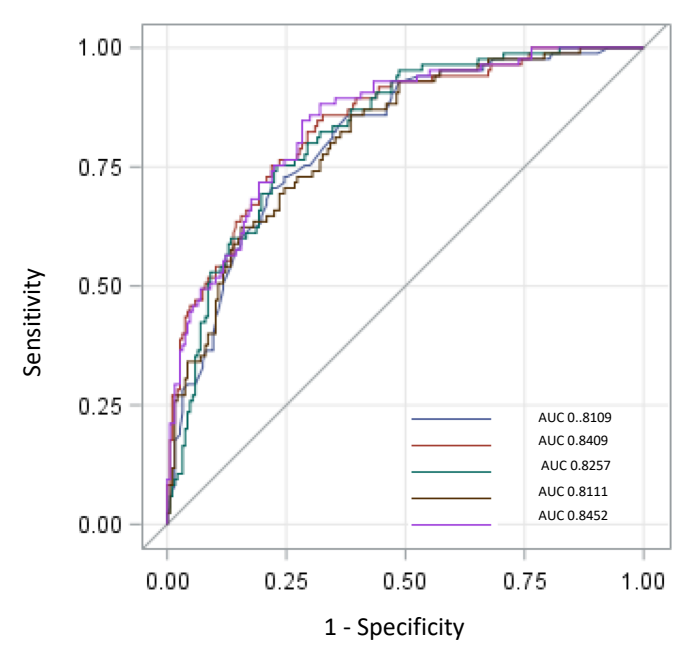

B

Figure 2. Results of ROC curve analyses for dementia by levels of total cholesterol.

A Receiver operating characteristics $(\mathrm{ROC})$ curve analyses for dementia with values of the corresponding areas under the curve (AUC) among participants with total cholesterol levels $<240 \mathrm{mg} / \mathrm{dL}$. The main model includes age, sex, educational level, and APOE $\varepsilon 4$ polymorphism ( $\varepsilon 2 \varepsilon 4, \varepsilon 3 \varepsilon 4, \varepsilon 4 \varepsilon 4$ vs $\varepsilon 2 \varepsilon 2, \varepsilon 3 \varepsilon 2, \varepsilon 3 \varepsilon 3)$. Glial Fibrillary Acidic Protein (GFAP), Neurofilament light (NfL), and tau phosphorylated at threonine 181 (P-tau 181) were inserted in the models as continuous variables. Main model; Main model + GFAP; Main model + NfL;

Main model + P-tau 181; Main model + GFAP, NfL, and P-tau 181.

B Receiver operating characteristics (ROC) curve analyses for dementia with values of the corresponding areas under the curve (AUC) among participants with total cholesterol levels $\geq 240 \mathrm{mg} / \mathrm{dL}$. The main model includes age, sex, educational level, and $A P O E \varepsilon 4$ polymorphism ( $\varepsilon 2 \varepsilon 4, \varepsilon 3 \varepsilon 4, \varepsilon 4 \varepsilon 4$ vs $\varepsilon 2 \varepsilon 2, \varepsilon 3 \varepsilon 2, \varepsilon 3 \varepsilon 3)$. Glial Fibrillary Acidic Protein (GFAP), Neurofilament light (NfL), and tau phosphorylated at threonine 181 (P-tau 181) were inserted in the models as continuous variables. Main model; $\quad$ Main model + GFAP; Main model + NfL; Main model + P-tau 181;

Main model + GFAP, NfL, and P-tau 181 
medRxiv preprint doi: https://doi.org/10.1101/2022.01.16.22269370; this version posted January 16,2022 . The copyright holder for this preprint (which was not certified by peer review) is the author/funder, who has granted medRxiv a license to display the preprint in perpetuity.

All rights reserved. No reuse allowed without permission.

Supplemental Table 1 Associations of high ${ }^{\mathrm{a}}$ GFAP with vascular dementia and Alzheimer's clinical syndrome by total cholesterol and APOE $\varepsilon 4$ status (ESTHER cohort study 2000-2017)

\begin{tabular}{|c|c|c|c|}
\hline & Overall & High TC $^{b}$ & Low TC ${ }^{c}$ \\
\hline $\begin{array}{l}\text { General population } \\
\text { ESTHER study } \\
(\mathrm{n}=768)\end{array}$ & $\begin{array}{l}\text { Odds ratio } \\
\text { (95\%Cl; } \\
\text { n= cases })\end{array}$ & $\begin{array}{l}\text { Odds ratio } \\
\text { (95\%Cl; } \\
\mathrm{n}=\text { cases })\end{array}$ & $\begin{array}{l}\text { Odds ratio } \\
\text { (95\% Cl; } \\
\text { n= cases) }\end{array}$ \\
\hline Vascular dementia & $\begin{array}{c}2.43 \\
(1.39-4.25) \\
(n=83)\end{array}$ & $\begin{array}{c}5.37 \\
(1.86-15.49) \\
(n=27)\end{array}$ & $\begin{array}{c}1.72 \\
(0.87-3.40) \\
(n=56)\end{array}$ \\
\hline $\begin{array}{l}\text { Alzheimer's clinical } \\
\text { syndrome }\end{array}$ & $\begin{array}{c}2.08 \\
(1.35-3.22) \\
(n=163) \\
\end{array}$ & $\begin{array}{c}2.10 \\
(1.00-4.41) \\
(\mathrm{n}=63)\end{array}$ & $\begin{array}{c}2.13 \\
(1.24-3.68) \\
(n=100) \\
\end{array}$ \\
\hline \multicolumn{4}{|l|}{$A P O E \varepsilon 4+^{d}$} \\
\hline Vascular dementia & $\begin{array}{c}4.02 \\
(1.40-11.52) \\
(n=25)\end{array}$ & $\begin{array}{c}9.54 \\
(1.02-89.58) \\
(n=8)\end{array}$ & $\begin{array}{c}2.50 \\
(0.72-8.75) \\
(n=17)\end{array}$ \\
\hline $\begin{array}{l}\text { Alzheimer's clinical } \\
\text { syndrome }\end{array}$ & $\begin{array}{c}1.85 \\
(0.97-3.53) \\
(n=76)\end{array}$ & $\begin{array}{c}1.33 \\
(0.47-3.75) \\
(n=34)\end{array}$ & $\begin{array}{c}2.42 \\
(1.03-5.67) \\
(n=42)\end{array}$ \\
\hline \multicolumn{4}{|l|}{ APOE $\varepsilon 4-^{\mathrm{e}}$} \\
\hline Vascular dementia & $\begin{array}{c}2.01 \\
(1.01-4.02) \\
(n=53)\end{array}$ & $\begin{array}{c}4.92 \\
(1.35-17.95) \\
(n=17)\end{array}$ & $\begin{array}{c}1.43 \\
(0.62-3.32) \\
(n=36)\end{array}$ \\
\hline $\begin{array}{l}\text { Alzheimer's clinical } \\
\text { syndrome }\end{array}$ & $\begin{array}{c}2.50 \\
(1.39-4.50) \\
(78)\end{array}$ & $\begin{array}{c}3.39 \\
(1.14-10.13) \\
(n=26)\end{array}$ & $\begin{array}{c}2.19 \\
(1.07-4.47) \\
(n=52)\end{array}$ \\
\hline
\end{tabular}

GFAP, Glial Fibrillary Acidic Protein; APOE, Apolipoprotein E; TC, total cholesterol; Cl, confidence interval.

f) $\geq$ quartile 4 (vs quartiles $1-3$ )

g) $\mathrm{TC} \geq 240 \mathrm{mg} / \mathrm{dL}$

h) $\mathrm{TC}<240 \mathrm{mg} / \mathrm{dL}$

i) participants carrying $A P O E \varepsilon 4$ genotype $(\varepsilon 2 \varepsilon 4, \varepsilon 3 \varepsilon 4, \varepsilon 4 \varepsilon 4)$

j) participants not carrying $A P O E \varepsilon 4$ genotype $(\varepsilon 2 \varepsilon 2, \varepsilon 3 \varepsilon 2, \varepsilon 3 \varepsilon 3)$

All models were adjusted for age, sex, educational level, $A P O E \varepsilon 4$ genotype, and TC. Subgroup analyses by TC were adjusted for age, sex, educational level, and $A P O E \varepsilon 4$. Subgroup analyses by $\mathrm{TC}$ and $A P O E \& 4$ genotype were adjusted for age, sex, and educational level. 
medRxiv preprint doi: https://doi.org/10.1101/2022.01.16.22269370; this version posted January 16,2022 . The copyright holder for this preprint (which was not certified by peer review) is the author/funder, who has granted medRxiv a license to display the preprint in perpetuity.

All rights reserved. No reuse allowed without permission.

Supplemental Table 2 Associations of high a NfL with vascular dementia and Alzheimer's clinical syndrome by total cholesterol and APOE $\varepsilon 4$ status (ESTHER cohort study 2000-2017)

\begin{tabular}{|c|c|c|c|}
\hline & Overall & High TC $^{b}$ & Low TC ${ }^{\mathrm{c}}$ \\
\hline $\begin{array}{l}\text { General population } \\
\text { ESTHER study } \\
(\mathrm{n}=768)\end{array}$ & $\begin{array}{l}\text { Odds ratio } \\
\text { (95\% Cl; } \\
\mathrm{n}=\text { cases })\end{array}$ & $\begin{array}{l}\text { Odds ratio } \\
\text { (95\%Cl; } \\
\text { n= cases })\end{array}$ & $\begin{array}{l}\text { Odds ratio } \\
\text { (95\% Cl; } \\
\text { n= cases) }\end{array}$ \\
\hline Vascular dementia & $\begin{array}{c}1.79 \\
(1.03-3.12) \\
(n=83)\end{array}$ & $\begin{array}{c}1.95 \\
(0.69-5.49) \\
(n=27)\end{array}$ & $\begin{array}{c}1.76 \\
(0.90-3.43) \\
(n=56)\end{array}$ \\
\hline $\begin{array}{l}\text { Alzheimer's clinical } \\
\text { syndrome }\end{array}$ & $\begin{array}{c}1.10 \\
(0.70-1.74) \\
(n=163)\end{array}$ & $\begin{array}{c}1.97 \\
(0.92-4.22) \\
(n=63)\end{array}$ & $\begin{array}{c}0.80 \\
(0.45-1.43) \\
(n=100) \\
\end{array}$ \\
\hline \multicolumn{4}{|l|}{$A P O E \varepsilon 4+^{d}$} \\
\hline Vascular dementia & $\begin{array}{c}0.91 \\
(0.31-2.63) \\
(n=25)\end{array}$ & $\begin{array}{c}0.81 \\
(0.13-4.98) \\
(n=8)\end{array}$ & $\begin{array}{c}0.94 \\
(0.25-3.58) \\
(n=17)\end{array}$ \\
\hline $\begin{array}{l}\text { Alzheimer's clinical } \\
\text { syndrome }\end{array}$ & $\begin{array}{c}1.01 \\
(0.49-2.09) \\
(n=76)\end{array}$ & $\begin{array}{c}2.39 \\
(0.77-7.41) \\
(n=34)\end{array}$ & $\begin{array}{c}0.56 \\
(0.21-1.49) \\
(n=42)\end{array}$ \\
\hline \multicolumn{4}{|l|}{ APOE ع4- } \\
\hline Vascular dementia & $\begin{array}{c}2.39 \\
(1.24-4.61) \\
(n=53)\end{array}$ & $\begin{array}{c}3.20 \\
(0.89-11.57) \\
(n=17)\end{array}$ & $\begin{array}{c}2.31 \\
(1.06-5.05) \\
(n=36)\end{array}$ \\
\hline $\begin{array}{l}\text { Alzheimer's clinical } \\
\text { syndrome }\end{array}$ & $\begin{array}{c}1.23 \\
(0.69-2.19) \\
(n=78)\end{array}$ & $\begin{array}{c}1.55 \\
(0.55-4.35) \\
(n=26)\end{array}$ & $\begin{array}{c}1.03 \\
(0.51-2.11) \\
(n=52)\end{array}$ \\
\hline
\end{tabular}

NfL, Neurofilament light; $A P O E$, Apolipoprotein $\mathrm{E} ; \mathrm{TC}$, total cholesterol; $\mathrm{Cl}$, confidence interval.
a) $\geq$ quartile 4 (vs quartiles 1-3)
b) $\mathrm{TC} \geq 240 \mathrm{mg} / \mathrm{dL}$
c) $\mathrm{TC}<240 \mathrm{mg} / \mathrm{dL}$
d) participants carrying $A P O E \varepsilon 4$ genotype $(\varepsilon 2 \varepsilon 4, \varepsilon 3 \varepsilon 4$, $\varepsilon 4 \varepsilon 4)$
e) participants not carrying $A P O E \varepsilon 4$ genotype $(\varepsilon 2 \varepsilon 2$, $\varepsilon 3 \varepsilon 2, \varepsilon 3 \varepsilon 3)$

All models were adjusted for age, sex, educational level, $A P O E \varepsilon 4$ genotype, and TC. Subgroup analyses by TC were adjusted for age, sex, educational level, and $A P O E \varepsilon 4$. Subgroup analyses by TC and APOE \&4 genotype were adjusted for age, sex, and educational level. 
medRxiv preprint doi: https://doi.org/10.1101/2022.01.16.22269370; this version posted January 16,2022 . The copyright holder for this preprint (which was not certified by peer review) is the author/funder, who has granted medRxiv a license to display the preprint in perpetuity.

All rights reserved. No reuse allowed without permission.

Supplemental Table 3 Associations of high a p-tau181 with vascular dementia and Alzheimer's clinical syndrome by total cholesterol and APOE $\varepsilon 4$ status (ESTHER cohort study 2000-2017)

\begin{tabular}{|c|c|c|c|}
\hline & Overall & High TC $^{b}$ & Low TC ${ }^{c}$ \\
\hline $\begin{array}{l}\text { General population } \\
\text { ESTHER study } \\
(\mathrm{n}=768)\end{array}$ & $\begin{array}{l}\text { Odds ratio } \\
\text { (95\% Cl; } \\
\mathrm{n}=\text { cases })\end{array}$ & $\begin{array}{l}\text { Odds ratio } \\
\text { (95\%Cl; } \\
\text { n= cases })\end{array}$ & $\begin{array}{l}\text { Odds ratio } \\
\text { (95\% Cl; } \\
\text { n= cases) }\end{array}$ \\
\hline Vascular dementia & $\begin{array}{c}1.76 \\
(1.03-3.03) \\
(n=83)\end{array}$ & $\begin{array}{c}3.36 \\
(1.33-8.49) \\
(n=27)\end{array}$ & $\begin{array}{c}1.21 \\
(0.61-2.39) \\
(n=56)\end{array}$ \\
\hline $\begin{array}{l}\text { Alzheimer's clinical } \\
\text { syndrome }\end{array}$ & $\begin{array}{c}1.25 \\
(0.81-1.92) \\
(n=163)\end{array}$ & $\begin{array}{c}0.96 \\
(0.46-2.00) \\
(n=63)\end{array}$ & $\begin{array}{c}1.44 \\
(0.84-2.46) \\
(n=100)\end{array}$ \\
\hline \multicolumn{4}{|l|}{$A P O E \varepsilon 4+^{\mathrm{d}}$} \\
\hline Vascular dementia & $\begin{array}{c}2.95 \\
(1.09-7.99) \\
(n=25)\end{array}$ & $\begin{array}{c}9.78 \\
(1.03-93.16) \\
(n=8)\end{array}$ & $\begin{array}{c}1.52 \\
(0.45-5.18) \\
(n=17)\end{array}$ \\
\hline $\begin{array}{l}\text { Alzheimer's clinical } \\
\text { syndrome }\end{array}$ & $\begin{array}{c}0.74 \\
(0.38-1.47) \\
(n=76)\end{array}$ & $\begin{array}{c}0.72 \\
(0.25-2.06) \\
(n=34)\end{array}$ & $\begin{array}{c}0.81 \\
(0.34-1.94) \\
(n=42)\end{array}$ \\
\hline \multicolumn{4}{|l|}{$A P O E \varepsilon 4--^{e}$} \\
\hline Vascular dementia & $\begin{array}{c}1.47 \\
(0.74-2.89) \\
(n=53)\end{array}$ & $\begin{array}{c}2.12 \\
(0.68-6.61) \\
(n=17)\end{array}$ & $\begin{array}{c}1.17 \\
(0.50-2.74) \\
(n=36)\end{array}$ \\
\hline $\begin{array}{l}\text { Alzheimer's clinical } \\
\text { syndrome }\end{array}$ & $\begin{array}{c}2.00 \\
(1.14-3 \cdot 52) \\
(n=78)\end{array}$ & $\begin{array}{c}1.48 \\
(0.54-4.08) \\
(n=26)\end{array}$ & $\begin{array}{c}2.33 \\
(1.17-4.64) \\
(n=52)\end{array}$ \\
\hline
\end{tabular}

p-tau181, tau phosphorylated at threonine 181; APOE, Apolipoprotein E; TC, total cholesterol; $\mathrm{Cl}$, confidence interval.
a) $\geq$ quartile 4 (vs quartiles $1-3$ )
b) $\mathrm{TC} \geq 240 \mathrm{mg} / \mathrm{dL}$
c) $\mathrm{TC}<240 \mathrm{mg} / \mathrm{dL}$
d) participants carrying APOE $\varepsilon 4$ genotype $(\varepsilon 2 \varepsilon 4, \varepsilon 3 \varepsilon 4, \varepsilon 4 \varepsilon 4)$
e) participants not carrying $A P O E \varepsilon 4$ genotype $(\varepsilon 2 \varepsilon 2, \varepsilon 3 \varepsilon 2, \varepsilon 3 \varepsilon 3)$

All models were adjusted for age, sex, educational level, APOE $\varepsilon 4$ genotype, and TC. Subgroup analyses by TC were adjusted for age, sex, educational level, and $A P O E \varepsilon 4$. Subgroup analyses by TC and $A P O E \& 4$ genotype were adjusted for age, sex, and educational level. 